\title{
Phenotypic features and analysis of genes supporting probiotic action unravel underlying perspectives of Bacillus velezensis VTX9 as a potential feed additive for swine
}

Ngoc Tung Quach ${ }^{1,2+}$, Thi Hanh Nguyen $\mathrm{Vu}^{1,2+}$, Ngoc Anh Nguyen ${ }^{1}$, Van The Nguyen ${ }^{1}$, Thi Lien Bui ${ }^{1}$, Son Chu Ky ${ }^{3}$, Tung Lam Le ${ }^{1}$, Ha Hoang ${ }^{1}$, Cao Cuong Ngo ${ }^{4}$, Thanh Thi Minh Le ${ }^{1}$, Trung Nam Nguyen ${ }^{1,2}$, Hoang Ha Chu ${ }^{1,2}$ and Quyet Tien $\mathrm{Phi}^{1}{ }^{1,2^{*}}$ (D)

\begin{abstract}
Purpose: To date, a total of 13 probiotic Bacillus species are considered as a Generally Recognized as Safe organism (GRAS) approved by the US Federal Food, Drug, and Cosmetic Act (FDCA), which are used for food and feed additives. However, Bacillus velezensis is not considered as a probiotic candidate in swine farming due to a lack of genetic basis of probiotic action-related traits. Therefore, the present study was undertaken to exploit the genetic basis underlying the probiotic traits of $B$. velezensis VTX9.

Methods: The genome sequencing of B. velezensis VTX9 was performed on a PacBio Sequel platform. The probiotic properties including biosafety, antioxidative capacity, and riboflavin and exopolysaccharide production were evaluated by using genotypic and phenotypic analysis. The secondary metabolite potentials were also predicted.

Results: Strain VTX9 isolated from swine feces proved some probiotic properties including resistance to $3 \mathrm{mM}$ $\mathrm{H}_{2} \mathrm{O}_{2}, 0.6 \mathrm{mM}$ bile salt, low pH, and antipathogenic activity. The complete genome of $B$. velezensis VTX9 consists of a 3,985,800 bp chromosome that housed 3736 protein-coding genes and 5 plasmids with the size ranging from 7261 to 20,007 bp. Genome analysis revealed no functional genes encoding enterotoxins and transferable antibiotic resistance, which confirmed the safety of VTX9. A total of 82 genes involved in gastrointestinal stress tolerance were predicted, which has not been reported previously. The maximum production of riboflavin reached $769 \pm 7.5 \mathrm{ng} / \mathrm{ml}$ in LB medium after $72 \mathrm{~h}$, which was in agreement with the complete de novo riboflavin biosynthetic pathway exploited for the first time in the B. velezensis genome. Antagonistic activity against pathogenic bacteria was attributed to 10 secondary metabolites clusters. The presence of a large gene cluster involved in biosynthesis of exopolysaccharides underscored further the adhesion and biofilm-forming capabilities of VTX9 in swine intestines.
\end{abstract}

\footnotetext{
* Correspondence: tienpq@ibt.ac.vn

${ }^{+} \mathrm{Ngoc}$ Tung Quach and Thi Hanh Nguyen Vu contributed equally to this work.

IInstitute of Biotechnology, Vietnam Academy of Science and Technology, Hanoi 10000, Vietnam

${ }^{2}$ Graduate University of Science and Technology, Vietnam Academy of

Science and Technology, Hanoi 10000, Vietnam

Full list of author information is available at the end of the article
}

(c) The Author(s). 2021 Open Access This article is licensed under a Creative Commons Attribution 4.0 International License, which permits use, sharing, adaptation, distribution and reproduction in any medium or format, as long as you give appropriate credit to the original author(s) and the source, provide a link to the Creative Commons licence, and indicate if changes were made. The images or other third party material in this article are included in the article's Creative Commons licence, unless indicated otherwise in a credit line to the material. If material is not included in the article's Creative Commons licence and your intended use is not permitted by statutory regulation or exceeds the permitted use, you will need to obtain permission directly from the copyright holder. To view a copy of this licence, visit http://creativecommons.org/licenses/by/4.0/. 
Conclusion: Our results revealed for the first time that B. velezensis VTX9 has the potential to be a probiotic candidate. The information provided here on the genome of B. velezensis VTX9 opens new opportunities for using $B$. velezensis as a feed additive for swine farming in the future.

Keywords: Antibiotic resistance, Bacillus velezensis, Biofilm formation, Complete genome sequencing, Probiotic, Riboflavin

\section{Introduction}

Probiotics are considered a safe alternative for the increasing use of antibiotics to improve the performance of livestock, leading to unprecedented attention over the world. Known as live microorganisms, the administration of probiotics has been demonstrated to improve growth performance and nutrient digestibility, prevent pathogen colonization, maintain mucosal and systemic immunity, and especially reduce antibiotic usage (Saulnier et al. 2009, Robles Alonso and Guarner 2013, Popova 2017). To date, the bacterial genera most frequently used as probiotics for animals are Lactobacillus, Bifidobacterium, Streptococcus, Enterococcus, and Bacillus (Holzapfel et al. 2001, Oliveira et al. 2017). Particularly, due to its cost-effective benefits, stability, and strong resistance to harsh gastric environments (Elshaghabee et al. 2017, Wu et al. 2019), the genus Bacillus is an outstanding candidate in animal farming.

Members of the genus Bacillus are Gram-positive endospore-forming bacilli that are widely distributed in human and animal gut commensals. Bacillus species have an indefinite shelf life and are strongly resistant to enormous stresses generated in the gastrointestinal tract, earning it a rising interest in the probiotic industry (Hong et al. 2005, Li et al. 2018). Many Bacillus spp.based products such as BioGrow ${ }^{\circ}$, BioPlus ${ }^{\circ} 2 \mathrm{~B}$, AlCare $^{\mathrm{TM}}$, and Sporlac $^{\oplus}$ are available on the market, which prove the efficacy of B. subtilis, B. licheniformis, B. clausii, and $B$. coagulans for animal feed and aquaculture (Khatri et al. 2016, Elshaghabee et al. 2017). With proposed scientific evidence, the safety, bile and acid tolerance, mucin-binding ability, and production of bacteriocins and vitamins contribute to the probiotic efficiency of the genus Bacillus (Khatri et al. 2016, Lee et al. 2019). B. subtilis, a Generally Recognized as Safe organism (GRAS), was reported to produce many bacteriocins, such as subtilin and subtilosin, to prevent the growth of livestock-associated pathogens including Salmonella enterica, Clostridium perfringens, and Escherichia coli (La Ragione et al. 2001, La Ragione and Woodward 2003, Khatri et al. 2016). The administration of B. subtilis resulted in the efficiency in treating acute infectious diarrhea, which is involved in adhesion and biofilmforming capabilities in the mucosal host (Allen et al.
2010). Exopolysaccharide (EPS) is one of the main factors contributing to these probiotic properties, protecting bacterial cells against gastrointestinal stress conditions (Caggianiello et al. 2016). EPS produced by probiotics are able to inhibit biofilm formation by pathogenic bacteria and harmful fecal enzymes such as $\beta$-glucosidase, $\beta$-glucuronidase, and tryptophanase (Bujnakova et al. 2014, Caggianiello et al. 2016). Another important probiotic property is the ability to produce riboflavin (vitamin B2) that is supplied to diets for improving pig production. To date, only B. subtilis, Ashbya gossypii, and Candida famata have been used for industrial riboflavin production (Averianova et al. 2020). The use of probiotics as in situ riboflavin supply is recognized as an attractive alternative to food fortification. Recent studies showed that probiotic B. clausii is also a producer of riboflavin (Paracchini et al. 2017, Khatri et al. 2019).

To date, $B$. velezensis is only known as ecologically safe biopesticides, fungicides, and plant-growth promoting rhizobacteria. Despite being reported firstly in 2008 as a heterotypic synonym of $B$. amyloliquefaciens, $B$. velezensis was re-classified as a big species by the addition of several species including $B$. methylotrophicus, B. amyloliquefaciens subsp. plantarum, and B. oryzicola (Dunlap et al. 2016). Plant growth promotion, production of a wide array of secondary metabolites against phytopathogens, and efficient colonization on plants are the outstanding characteristics of $B$. velezensis that makes itself highly cited as a biocontrol agent (Cai et al. 2017, Balderas-Ruíz et al. 2020, Zhu et al. 2020). A recent report demonstrated that the use of $B$. velezensis as a feed additive enhanced the production performance, egg quality, and especially replaced the feed antibiotics such as flavomycin in laying hen farming (Ye et al. 2020). In 2020, only B. velezensis DSM 15544 was listed for the first time on the Qualified Presumption of Safety (QPS) approved by The European Union Food Safety Authority (EFSA) and Generally Recognized as Safe (GRAS) status by the US Food and Drug Administration, which confirmed the safety and efficacy of this species in swine farming (Additives et al. 2020). However, no report was done to demonstrate systematically the probiotic properties of $B$. velezensis at both phenotypic and genetic levels. 
Sequencing and functional annotation of the genome is an effective approach to rapidly evaluate genetic determinants involved in probiotic potential. Although a total of 348 genome sequences have been deposited on the GenBank database, no report exploits the genetic basis underlying the probiotic characteristics of $B$. velezensis in swine farming. In this study, we carried out the complete genome sequencing of B. velezensis VTX9 isolated from swine feces. Probiotic traits including safety, oxidative stress, low $\mathrm{pH}$ and bile salt tolerance, secondary metabolite and vitamin production, and adhesive ability were evaluated through genotypic and phenotypic analysis in order to gain insights into the molecular basis of probiotic function exerted by the probiotic candidate.

\section{Materials and methods}

\section{Isolation and characterization of the strain VTX9}

The fecal samples collected at several swine farms in Hanoi, Vietnam were heat-treated $\left(80{ }^{\circ} \mathrm{C}\right.$ for $\left.10 \mathrm{~min}\right)$ to kill all vegetative cells and spread on Bacillus agar medium (Himedia, India). The plates were inoculated at $37^{\circ} \mathrm{C}$ for $24 \mathrm{~h}$ under aerobic conditions. The isolate was subsequently purified by streaking on the fresh Bacillus agar medium and then stored at $-80{ }^{\circ} \mathrm{C}$ as glycerol $(40 \%)$ stock for further studies. Cell morphology and spore of strain VTX9 were visualized by scanning electron microscopy (SEM) JSM-5410 (JEOL, Tokyo, Japan). The effects of different conditions, including $\mathrm{pH}$, temperature, $\mathrm{NaCl}$, carbon, and nitrogen sources, on the growth of strain VTX9 were performed as described previously (Fan et al. 2017). The ability to produce extracellular enzymes including catalase, oxidase, amylase, protease, and cellulase, was performed as described formerly by Gopalakrishnan et al. 2011. The antibiotic susceptibility patterns of strain VTX9 were examined against 12 antibiotics by using the disc diffusion test (Rechenchoski et al. 2017). The test discs were amikasin $(30 \mu \mathrm{g})$, nalidixic acid $(30 \mu \mathrm{g})$, kanamycin $(30 \mu \mathrm{g})$, neomicin $(30 \mu \mathrm{g})$, chloramphenicol $(30 \mu \mathrm{g})$, gentamicin $(10$ $\mu \mathrm{g})$, ciprofloxacin $(5 \mu \mathrm{g})$, meropenem $(10 \mu \mathrm{g})$, ceftazime $(30 \mu \mathrm{g})$, fosfomycin $(200 \mu \mathrm{g})$, tetracycline $(30 \mathrm{UI})$, and levofloxacin $(5 \mu \mathrm{g})$.

\section{DNA extraction, PCR amplification, and 16S rRNA gene sequence analysis}

Total genomic DNA was extracted from VTX9 bacterial suspension using G-spin ${ }^{\text {Tx }}$ Total DNA Extraction Mini Kit (Intron Bio) according to the manufacturer's instructions. The 16S rRNA gene was amplified by using the universal primer pair 27F (5'-TAACACATGCAAGT CGAACG-3') and 1429R (5'-GGTGTGACGGGCGG TGTGTA-3'). About $100 \mathrm{ng}$ of DNA template was added to a PCR mixture $(50 \mu \mathrm{l})$ containing $1 \times$ Taq Master, $1 \times$ PCR buffer, $2.75 \mathrm{mM} \mathrm{MgCl} 2,0.06 \mathrm{mM}$ dNTP, 20 pm of each primer, $2 \mathrm{U}$ Taq DNA polymerase (Eppendorf, Westbury, NY). The PCR conditions composed of an initial denaturation at $94{ }^{\circ} \mathrm{C}$ for $2 \mathrm{~min}, 35$ cycles at 94 ${ }^{\circ} \mathrm{C}$ for $1 \mathrm{~min}, 55^{\circ} \mathrm{C}$ for $1.5 \mathrm{~min}$, and $72{ }^{\circ} \mathrm{C}$ for $1 \mathrm{~min}$; and a final extension step consisting of $72{ }^{\circ} \mathrm{C}$ for $10 \mathrm{~min}$. The PCR products was run on $1 \%$ agarose gel, stained with ethidium bromide, and visualized with the Gel Doc EZ Imager (Bio-Rad Laboratories Inc.). Afterwards, the purified PCR products were sent to First BASE Laboratories Sdn. Bhd. (Malaysia) for Sanger sequencing. The obtained sequence of strain VTX9 was compared with the representative 16S rRNA gene sequences of related type strains using the Basic Local Alignment Search Tool program (BLAST; https://blast.ncbi.nlm.nih.gov/ Blast.cgi). The phylogenetic tree was computed by using the neighbor-joining method with 1000 bootstrap in MEGA version 7.0. Numbers at nodes indicate the percentages of 1000 bootstrap re-samplings and Lactobacillus paracasei ATCC 25302 (NR 117987) was used as the outgroup branch. The 16S rRNA gene sequence of strain VTX9 was deposited onto the GenBank (NCBI) under accession number MZ127796.

\section{Genome sequencing, de novo assembly, and annotation} Whole-genome sequencing of strain VTX9 was implemented by using the Pacific Bioscience SEQUEL platform (Menlo Park, CA, USA) with single-molecule realtime (SMRT) sequencing by the Institute of Biotechnology, Vietnam Academy of Science and Technology. The raw reads were generated, and de novo assembled into one contig using the CLC Genomics Workbench version 7.5.1 (CLC Bio, Aarhus, Denmark) with the hierarchical genome-assembly process (HGAP) algorithm in SMRT analysis. The complete genome was annotated using Prokaryotic Genomes Annotation Pipeline (PGAP) at NCBI and Rapid Annotations using Subsystem Technology (RAST) (Overbeek et al. 2014, Tatusova et al. 2016). Orthologous genes were analyzed using clusters of orthologous genes (COGs) (Galperin et al. 2015). Annotation indicating the biological processes, molecular functions, and cellular components were evaluated using InterProScan 5 (Jones et al. 2014). The complete sequences of the chromosome and five plasmids of VTX9 were deposited in the NCBI GenBank database.

\section{ANI comparison and identification of the antibiotic resistome, virulome, secondary metabolite clusters, riboflavin, and EPS biosynthetic pathways}

In order to identify strain VTX9 at genomic levels, average nucleotide identity (ANI) was conducted to measure the overall similarity between Bacillus genome sequences using OrthoANI with default parameters (Lee et al. 2016). Heat map was generated with OrthoANI values that were calculated from Orthologous Average 
Nucleotide Identity Tool. Antimicrobial resistance and virulence genes residing in the genome of strain VTX9 were screened via the functional annotation data generated from Pathosystems Resource Integration Center (PATRIC) platform (Snyder et al. 2007) and Comprehensive Antibiotic Resistance Database (CARD) (Jia et al. 2017). The CRISPRCasFinder, a web tool, was used for the prediction of the Clustered Regularly Interspaced Palindromic Repeats (CRISPRs) sequence in the chromosome of the strain VTX9 (Couvin et al. 2018). Regarding bioactive potential, the genome of VTX9 was analyzed for the presence of secondary metabolites BGCs using antibiotic and Secondary Metabolite analysis shell (antiSMASH) version 4.0 (Blin et al. 2017) and BAGEL3 (Hart and Moffat 2016). The genes involved in riboflavin and EPS biosynthesis were determined by using BLAST of NCBI and Rapid Annotations using Subsystems Technology (RAST) (Aziz et al. 2008).

\section{Antibacterial activity}

The antibacterial activity of the VTX9 culture supernatant was investigated using the agar diffusion method as described previously ( $\mathrm{Vu}$ et al. 2018, Quach et al. 2021). Human pathogenic bacteria, including Escherichia coli ATCC 11105, Salmonella typhimurium ATCC 14028, Pseudomonas aeruginosa ATCC 9027, Staphylococcus epidermidis ATCC 12228, Micrococcus luteus ATCC 9341, and Staphylococcus aureus ATCC 6538 were used in this study. Diameters of the inhibition zones were measured using a zone scale and expressed in millimeters. The experiment was carried out in triplicate.

\section{Oxidative stress, $\mathrm{pH}$, and bile salt tolerance}

The strain VTX9 was grown as overnight culture in LB medium at $37{ }^{\circ} \mathrm{C}$ under vigorous agitation. To evaluate the response of VTX9 to stress conditions, an optical density at $600 \mathrm{~nm}\left(\mathrm{OD}_{600}\right)$ of 0.1 of bacterial cells was grown in the fresh LB medium containing different concentration of $\mathrm{H}_{2} \mathrm{O}_{2}(0,0.5,1,2,3 \mathrm{mM}), \mathrm{pH}(\mathrm{pH} 2.0, \mathrm{pH}$ 3.0, pH 4.0, pH 5.0), and ox-bile (0, 0.2, 0.4, 0.6\%). The cultures were incubated in the shaking machine at $37^{\circ} \mathrm{C}$ with continuous shaking, and cell growth was observed spectrophotometrically at $600 \mathrm{~nm}$ every hour.

\section{Quantification of riboflavin production}

Bacillus velezensis VTX9 was propagated in the LB medium at $37{ }^{\circ} \mathrm{C}$ overnight. The overnight culture was transferred to a new riboflavin production medium (yeast extract $4.0 \mathrm{~g}$, fructose $38.1 \mathrm{~g}, \mathrm{MgSO}_{4}, 0.85 \mathrm{~g}$, $\mathrm{K}_{2} \mathrm{HPO}_{4} .2 .2 \mathrm{~g}, \mathrm{FeSO}_{4} 0.02 \mathrm{~g}, \mathrm{pH} 6.8-7.0$ in a liter) and adjusted to an optical density at $600 \mathrm{~nm}$ of 0.1 . At intervals, the culture was centrifuged at $4{ }^{\circ} \mathrm{C}, 10,000 \mathrm{rpm}$ for $10 \mathrm{~min}$ to obtain the supernatant. Cell-free supernatant was used to determine riboflavin production. Quantification of riboflavin level was performed by using HPLC with a Fluorescence detector (Shimadzu, Japan) (Juarez del Valle et al. 2014). Detection was conducted by a fluorescent detector. The excitation and emission wavelengths were 445 and $530 \mathrm{~nm}$, respectively. Riboflavin was eluted in isocratic conditions using a mobile phase consisting of $0.05 \mathrm{M}$ sodium acetate/methanol (30:70, v/ v). A standard curve was constructed with different dilutions of riboflavin.

\section{EPS production and isolation}

$B$. velezensis VTX9 was grown as an overnight culture in the LB medium at $37^{\circ} \mathrm{C}$. The overnight culture was then transferred to EPS medium (sucrose/glucose source, yeast extract $2.0 \mathrm{~g},\left(\mathrm{NH}_{4}\right)_{2} \mathrm{SO}_{4} 1.5 \mathrm{~g}, \mathrm{~K}_{2} \mathrm{HPO}_{4} 2.5 \mathrm{~g}$, pH 7.0 per liter) as described (Ruas-Madiedo and de los Reyes-Gavilán 2005) and adjusted to an optical density at $600 \mathrm{~nm}\left(\mathrm{OD}_{600}\right)$ of 0.1. Effect of sucrose/glucose concentrations on EPS production was studied by the supplement of 0-150 g/L sugar source in the EPS medium. After $48 \mathrm{~h}$, EPS was isolated from cell-free supernatant through the addition of 3-fold cold ethanol, which subsequently was chilled at $4{ }^{\circ} \mathrm{C}$ overnight for complete precipitation. After centrifugation at 10,000 rpm for $20 \mathrm{~min}$, precipitated EPS was washed twice with chilled ethanol, then was freeze-dried, and weighed to determine raw EPS concentration, expressed as $\mathrm{g} / \mathrm{l}$.

\section{Results}

\section{Identification of the strain VTX9}

A total of 12 spore-forming isolates with distinct morphology were isolated from swine feces. The growth of these spore formers at different $\mathrm{H}_{2} \mathrm{O}_{2}, \mathrm{pH}$, and ox bile were performed to screen for potential probiotic isolates. Out of 12 isolates, only isolate VTX9 was able to grow on LB medium supplemented with $3 \mathrm{mM} \mathrm{H}_{2} \mathrm{O}_{2}$ and $0.6 \%$ ox bile (Fig. 1a, c), and prefered acidic pH such as pH 4 (Fig. 1b). Moreover, VTX9 proved to have significant activity against all the pathogenic bacteria, including E. coli ATCC $11105(28.3 \pm 0.5 \mathrm{~mm}), \quad S$. typhimurium ATCC $14028(12.1 \pm 0.9 \mathrm{~mm})$, S. epidermidis ATCC $12228(22.2 \pm 1.1 \mathrm{~mm})$, M. luteus ATCC 9341 $(28.3 \pm 1.0 \mathrm{~mm})$, S. aureus ATCC $6538(16.3 \pm 1.1 \mathrm{~mm})$ (Fig. 1d).

The isolate VTX9 was observed as Gram-positive, aerobic, and spore-forming bacterium. As viewed under SEM, the cells were rod-shaped with rough outer surfaces and produced sticky material when grown on EPS liquid medium (Fig. S1). When heated at $80{ }^{\circ} \mathrm{C}$ for 20 min, the isolate VTX9 produced spores that were ellipsoidal. The colonies grown on LB agar were circular and flat with a serrated edge, rough surface, and viscous. The temperature range of $25-45{ }^{\circ} \mathrm{C}, \mathrm{pH}$ range of $2-9$, and 

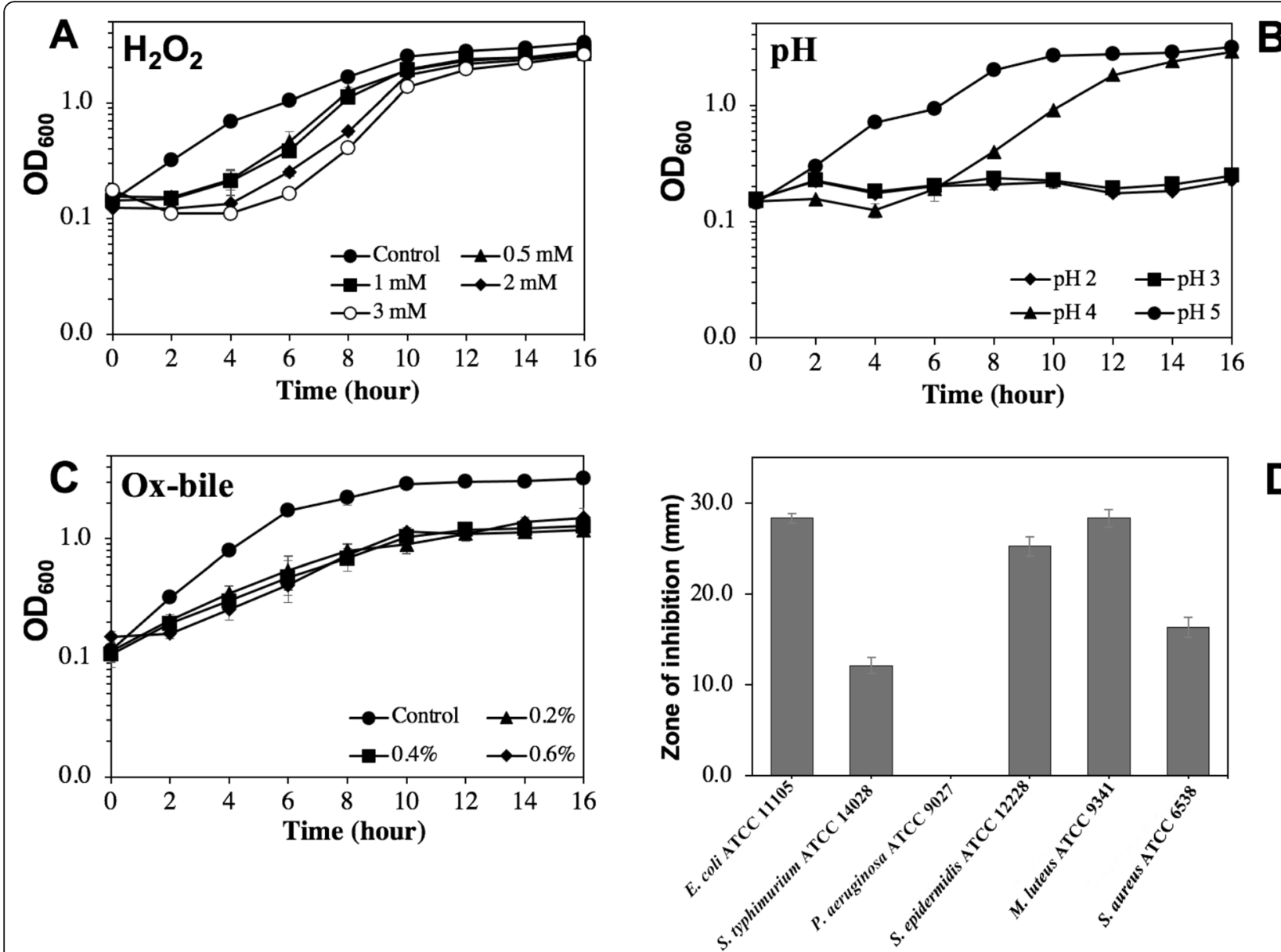

D

Fig. 1 Growth curves under different stress conditions including $\mathrm{H}_{2} \mathrm{O}_{2}(\mathbf{a})$, acidic $\mathrm{pH}(\mathbf{b})$, and ox-bile (c), and antibacterial activity (d) of isolated strain VTX9

$\mathrm{NaCl}$ range of $1-8 \%$ were sufficient for the growth of VTX9 (Table S1). The biochemical tests of isolate VTX9 included the ability to produce an array of extracellular enzymes, including catalase, oxidase, amylase, protease, cellulase, and utilize various sole carbon sources, such as glucose, lactose, inositol, Draffinose, D-fructose, D-sorbitol, and methyl- $\alpha-\mathrm{D}$ glycoside. In addition, this isolate gave negative tests for mannitol, melibiose, and D-turanose (Table S1). The strain VTX9 showed similar morphological and biochemical characteristics to the type strain Bacillus velezensis $\mathrm{CR}-502^{\mathrm{T}}$. Utilization of mannitol and susceptibility to ceftazidime were the differences between VTX9 and Bacillus velezensis CR-502 ${ }^{\mathrm{T}}$.

The 16S rRNA of strainVTX9 was around 99.7\% identical to that of B. velezensis CR-502 ${ }^{\mathrm{T}}$ (AY603658) and B. velezensis $\mathrm{BCRC} 17467^{\mathrm{T}}$ (EF433407). Moreover, the 16S rRNA gene sequence of VTX9 also shared high similarities with other Bacillus species such as B. amyloliquefaciens DSM $7^{\mathrm{T}}$ (99.6\%), B. mojavensis DSM $9205^{\mathrm{T}}$ (99.4\%), B. atrophaeus DSM $7264^{\mathrm{T}}$ (99.4). Furthermore, the neighbor-joining phylogenetic tree indicated that VTX9 and B. velezensis were in the same branch (Fig. 2a). To make the identification more accurate, the OrthoANI software was used to determine the OrthoANI values among the isolate VTX9 and six closely related Bacillus species. Analysis of OrthoANI values indicated that the strain VTX9 had 76.9-97.7\% genome sequence identities with other species (Fig. 2b). VTX9 showed the highest OrthoANI value of $97.71 \%$ with B. velezensis LS69 (accession number CP015911) and 97.69\% with B. velezensis FZB42 (accession number NC_009725), which was significant enough for species demarcation. Based on the phenotypic characteristics, the 16S rRNA gene sequence and ANI analysis, strain VTX9 should be classified as B. velezensis VTX9, which then was deposited at VAST-Culture Collection of Microorganisms (VCCM, www.vccm.vast.vn) with the accession number VCCM 14174. 


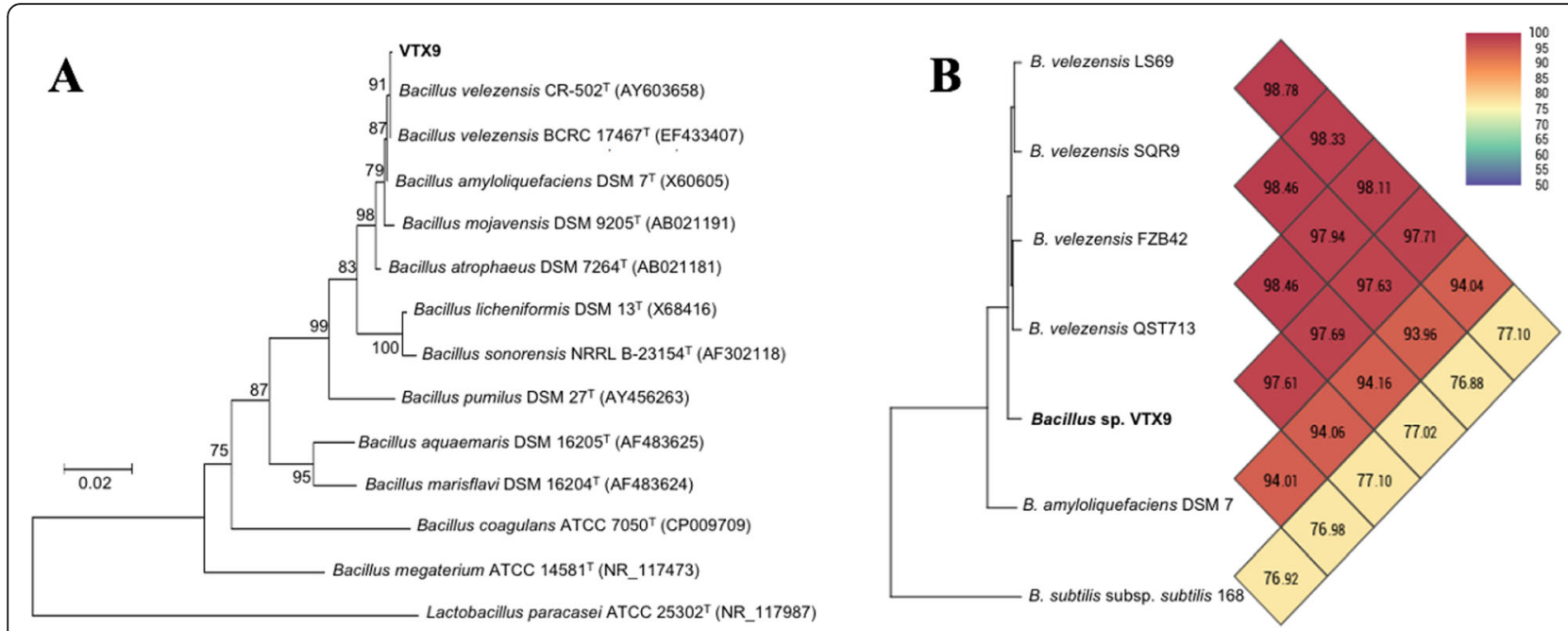

Fig. 2 Phylogenetic tree based on 16S rRNA gene sequences (a) and OrthoANI values (b) showing the relationship of strain VTX9 with strains of closely related species

\section{Genome sequence and general features of the $B$. velezensis strain VTX9}

Using the PacBio platform, the complete genome of $B$. velezensis VTX9 was found to contain a circular chromosome of 3,985,800 bp with the average GC content of $46.1 \%$ (Fig. 3a) and five distinct plasmids whose length ranges from $7261 \mathrm{bp}$ to $20,007 \mathrm{bp}$ (Fig. 3b). Five circular plasmids include pVTX9-1 (20,007 bp with $37.6 \% \mathrm{G}+\mathrm{C}$ ), pVTX9-2 (8565 bp with $39.9 \% \mathrm{G}+\mathrm{C})$, pVTX9-3 (18,221 bp with 35.3\% G + C), pVTX9-4 (12,395 bp with $38.1 \% \mathrm{G}+\mathrm{C}$ ), pVTX9-5 (7261 bp with $42.2 \% \mathrm{G}+\mathrm{C}$ ) (Table S2). Additionally, the annotation pipeline generated a total of 3736 protein-coding genes (CDSs), 86 tRNA genes, 27 rRNA genes, and 110 pseudogenes. The genomic feature of strain VTX9 falls in the size range reported for $B$. velezensis species. In addition, this is the first report showing the largest number of plasmids found in a single B. velezensis strain. The largest plasmid contains 28 CDSs whose the average GC content of $37.6 \%$ that is higher than most B. velezensis strains that were reported around $8 \mathrm{~kb}$ in size (Chen et al. 2018), except for B. velezensis GH1-13 comprising of a unique plasmid with the size of $71.6 \mathrm{~kb}$ (Kim et al. 2017).

Functional annotation of the entire genome of $B$. velezensis VTX9 showed that primary virulence factors of food-borne and food-poisoning pathogens, including hemolysin ( $h b l A, h b l C, h b l D)$, non-hemolytic (nheA, nheB, nhe $C$ ), emetic toxin (ces $A, \operatorname{ces} B, \operatorname{ces} C$, cesD), and onecomponent cytotoxin $\mathrm{K}(c y t K)$ were absent. The transferrable antibiotic resistance genes were not found in chromosome and five plasmids using the ResFinder software.

\section{Lifestyle adaption and antioxidative capacity}

Probiotic Bacillus species must survive under oxidatively hostile environments in the gastrointestinal tract due to prolonged luminal oxidant exposure, exogenous stimuli, or imbalanced microbiota (Wu et al. 2019). Four important genes responsible for the biosynthesis of bacillithiol (BSH), a low-molecular-weight thiol involved in the defense against oxidative stress were identified, which includes glycosyltransferase BshA (orf_815), deacetylase BshB1 (orf_ 814) and BshB2 (orf_1004), and cysteine ligase BshC (orf 1517) (Table 1). In response to excessive reactive oxygen species (ROS), BSH forms mixed disulfides with redox proteins, named $S$-bacillithiolations, which are reduced by bacilliredoxins such as BrxA (orf_139), BrxB (orf_632), and BrxC (orf_939). NADPH-dependent flavin disulfide reductase YpdA (orf_763) acts together with the BrxAB pathway in the de-bacillithiolation of proteins. In line with BrxABC/ BSH/YpdA determined, 5 genes (orf_132, orf_280, orf_1472, orf_2778, orf_3892) and 4 genes (orf_763, orf_2717, orf_ 3665, orf_3963) annotated as thioredoxin (trx) and thioredoxin reductase $(\operatorname{tr} x R)$ (Table 1$)$, respectively play an important role in maintaining a reducing intracellular environment for cell viability (Arnér and Holmgren 2011).

Regarding enzymatic antioxidant, B. velezensis VTX9 harbors three copies of catalase (kat; orf_2172, orf_3239, orf_3266) and two copies of alkyl hydroperoxide reductase (ahp; orf_3146, orf_3147) strictly regulated by peroxide stress regulator PerR (orf_2188) (Table 1). Given that organic hydroperoxide resistance $o h r$ and its regulator ohrR contribute mainly to detoxification of organic hydroperoxide stress, two operons including ohrB-ohrR$o h r A 1$ and ohrR-ohrA2 were present in the chromosome, which is unusual in Bacillus species. 


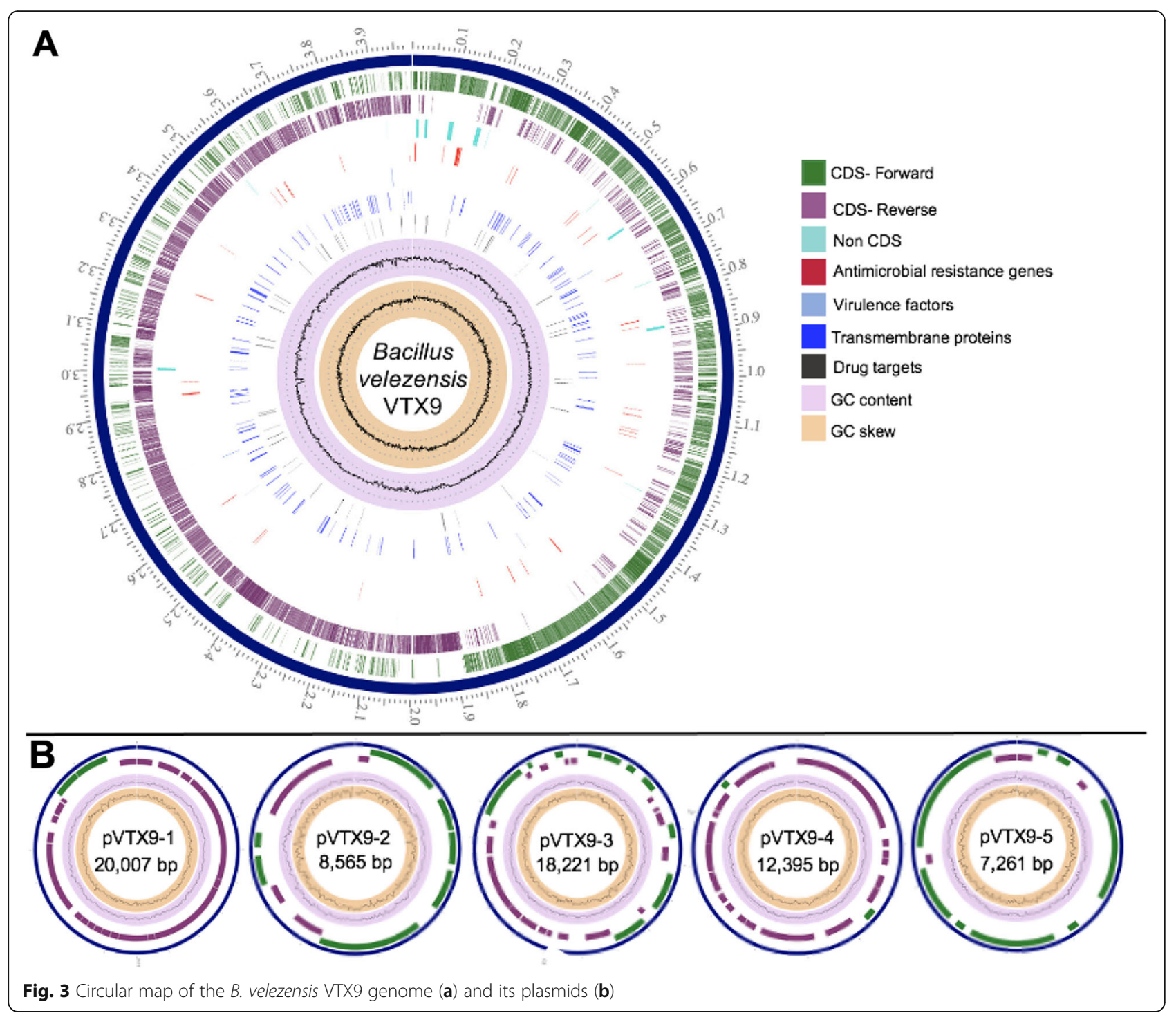

When exposed to an acidic environment, B. velezensis VTX9 employs 8 ATP synthase atp genes clustered together in an operon (atp operon) to maintain $\mathrm{H}^{+}$ homeostasis via hydrolyzing ATP to pump protons $\left(\mathrm{H}^{+}\right)$ from the cytoplasm. Various genes involved in glucose catabolism were attributed to $\mathrm{pH}$ resistance-related genes such as three glucose transport proteins (orf_3271, orf_3283, orf_3299) and one glucose-6-phosphate isomerase (orf_2), pyruvate kinase (orf_203), and phosphoglycerate kinase (orf_3742) (Table 1). As known that bile stress induces intracellular acidification and disrupt bacterial membranes (Begley et al. 2005), 15 gene encoding proteins annotated as oligopeptide $\mathrm{ABC}$ transporter, ribosomal protein, glucosamine-6-phosphate deaminase, CTP synthase, arginyl-tRNA synthetase, choloylglycine hydrolase, and inorganic pyrophosphatase were predicted to be involved in bile tolerance.

\section{Riboflavin production}

Another important property of B. velezensis VTX9 was its capability to synthesize riboflavin. All genes responsible for de novo riboflavin biosynthesis are present in the genome of VTX9. The set of genes consists of a complete rib operon including ribD (orf_729), ribE (orf 730), ribBA (orf_731), ribH (orf_732), and ribT (orf_733), in which the function of the $r i b T$ gene remains unclear to date, clustered in the same orientation in a predicted $3.9 \mathrm{~kb}$ operon structure (Fig. 4a). Four genes encode the key enzymes for riboflavin biosynthesis from guanosine triphosphate and ribulose-5-phosphate. The genome also contains unconnected ribF (orf_1356) homologue encoding a bifunctional riboflavin kinase/FMN adenylyltransferase catalyzing the conversion of riboflavin to FMN and FAD. Of note, VTX9 employs 3 genes encoding putative riboflavin transporters ribZ (orf_438, orf_3487, 
Table 1 Stress-related genes predicted in the genome of B. velezensis VTX9

\begin{tabular}{|c|c|c|c|}
\hline Stress & Stress-related protein & Gene & Locus tag \\
\hline \multirow[t]{20}{*}{ Oxidative stress } & Superoxide dismutase & sod & orf_522, orf_1012, orf_1021 \\
\hline & $\mathrm{N}$-acetylglucosaminyl L-malate synthase & bshA & orf_815 \\
\hline & $\mathrm{N}$-acetylglucosaminyl-L-malate deacetylase & bshB12 & orf_814, orf_1004 \\
\hline & Glucosaminyl-malate cysteine ligase & bshc & orf_1517 \\
\hline & Bacilliredoxin & $b r x A B C$ & orf_139, orf_632, orf_939 \\
\hline & Bacillithiol dilsufide reductase & ypdA & orf_763 \\
\hline & $\mathrm{NADH}$ - oxidoreductase & - & orf_608, orf_651, orf_2543 \\
\hline & Catalase & kat & orf_2172, orf_3239, orf_3266 \\
\hline & Thiol peroxidase & $\operatorname{tpx}$ & orf_180, orf_2189 \\
\hline & Glutathione peroxidase & $g p x$ & orf_935 \\
\hline & Alkyl hydroperoxide reductase & $a h p$ & orf_3146, orf_3147 \\
\hline & Bacillopeptidase & $b p r$ & orf_1500, orf_1501 \\
\hline & Manganese catalase & $y d b D$ & orf_2341, orf_2441, orf_2588 \\
\hline & Peroxide stress regulator & perR & orf_2188 \\
\hline & Organic hydroperoxide regulator & ohrR & orf_1732, orf_2546 \\
\hline & Organic hydroperoxide resistance & ohr & orf_1731, orf_1733, orf_2547 \\
\hline & Nitric oxide dioxygenase & hmp & orf_25, orf_159 \\
\hline & Thioredoxin & $\operatorname{trx}$ & orf_132, orf_280, orf_1472, orf_2778, orf_3892 \\
\hline & Thioredoxin reductase & $\operatorname{trx} R$ & orf_763, orf_2717, orf_3665, orf_3963 \\
\hline & Glyceraldehyde-3-phosphate dehydrogenase & gapDH & orf_225, orf_3740 \\
\hline \multirow[t]{10}{*}{ Acid stress } & ATP synthase & atp & orf_3445, orf_3446, orf_3447, orf_3448, orf_3449, orf_3450, orf_3451, orf_3452 \\
\hline & PTS system & ptcC & orf_3271, orf_3283, orf_3299 \\
\hline & Glucose-6-phosphate isomerase & pgi & orf_2 \\
\hline & Pyruvate kinase & pyk & orf_203 \\
\hline & Phosphoglycerate kinase & pgk & orf_3742 \\
\hline & RecA protein & recA & orf_1326 \\
\hline & ATP-dependent Clp protease & $c l p$ & orf_1673 \\
\hline & GTP pyrophosphokinase & rel & orf_370, orf_1899, orf_3293 \\
\hline & Enolase & eno & orf_3745 \\
\hline & Chaperone protein & dnak & orf_474 \\
\hline \multirow[t]{7}{*}{ Bile stress } & Glucosamine-6-phosphate deaminase & $n a g B$ & orf_3643 \\
\hline & CTP synthase & pyrG & orf_3414 \\
\hline & Arginyl-tRNA synthetase & $\operatorname{args}$ & orf_3397 \\
\hline & Oligopeptide ABC transporter & oppA & orf_1917, orf_1918, orf_1925, orf_1926, orf_2177 \\
\hline & Ribosomal protein & $r p s / r p l$ & orf_2895, orf_2897, orf_2900, orf_2906, orf_2911, \\
\hline & Choloylglycine hydrolase & chb & orf_3265 \\
\hline & Inorganic pyrophosphatase & PPase & orf_3083 \\
\hline
\end{tabular}

orf_3628) that facilitate riboflavin uptake from outside of the cell membrane (Fig. $4 \mathrm{a}$ ).

Riboflavin production of B. velezensis VTX9 was evaluated after $24 \mathrm{~h}, 48 \mathrm{~h}$, and $72 \mathrm{~h}$. The riboflavin concentration reached $182 \pm 1.0 \mathrm{ng} / \mathrm{ml}$ and $333 \pm 44.9 \mathrm{ng} / \mathrm{ml}$ in the un-optimized medium after $24 \mathrm{~h}$ and $48 \mathrm{~h}$, respectively (Fig. 4b). Surprisingly, the maximum riboflavin production was achieved after $72 \mathrm{~h}(769 \pm 7.5 \mathrm{ng} / \mathrm{ml})$ which was about 4.2-fold higher than that of $24 \mathrm{~h}$ of incubation.

\section{Secondary metabolite biosynthetic gene clusters in strain VTX9}

B. velezensis is known as the producer of enormous bioactive secondary metabolites (Reva et al. 2019, Zhu et al. 

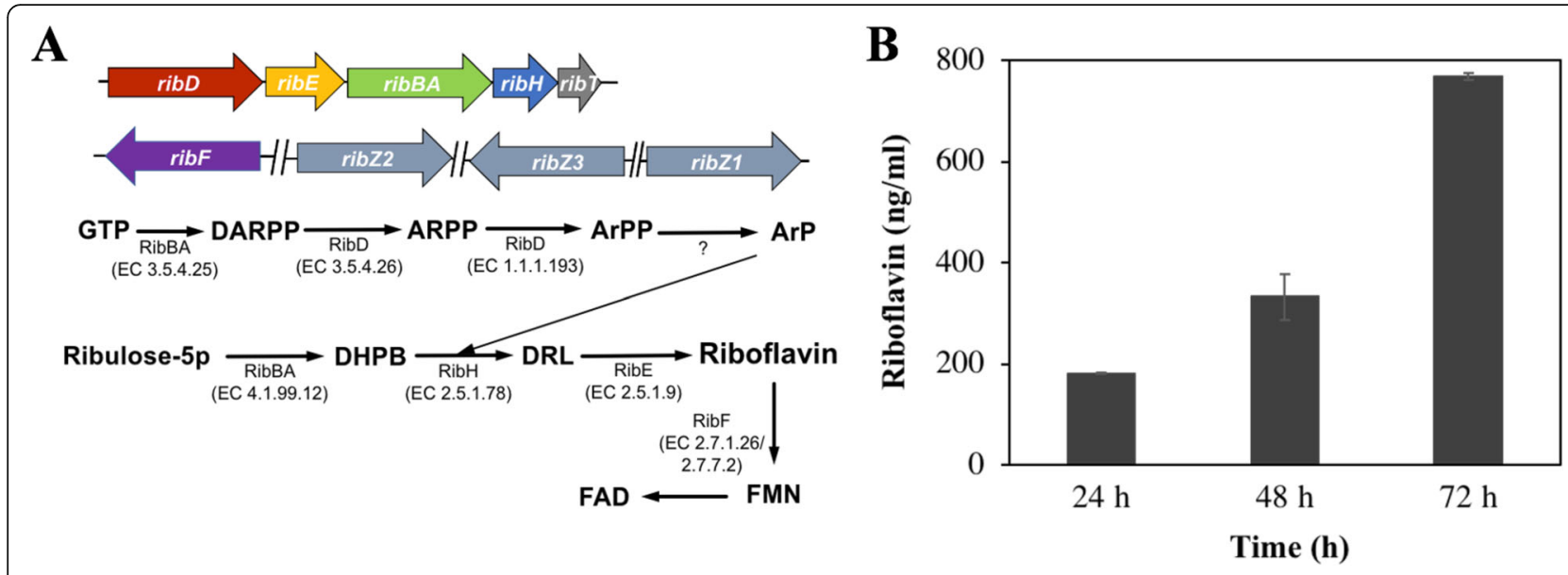

Fig. 4 The proposed riboflavin biosynthetic pathway (a) and riboflavin production observed in B. velezensis VTX9 (b)

2020). Using antiSMASH, a total of 10 such clusters were predicted in the genome of strain VTX9, including four coding non-ribosomal peptide synthetase (NRPS), two trans-acyl transferase polyketide synthetase (TransAT PKS), two transATP KS-NRPS, one ketosynthase (KS), and one saccharide (Table 2). Indeed, eight clusters were clearly involved in the biosynthesis of macrolactin, bacillaene, fengycin, difficidin, bacillibactin, surfactin, teichuronic acid, and bacilysin due to high similarity BGC (> 82\%). By contrast, cluster 5 showed a $17 \%$ amino acid similarity with a molybdenum cofactor synthetase gene cluster, and cluster 10 showed a $7 \%$ amino acid similarity with a butirosin gene cluster. Moreover, the VTX9 genome possesses 10 unexplored silent secondary metabolite biosynthetic gene clusters. Among predicted clusters, 8 clusters were known to confer resistance against pathogenic bacteria (difficidin, bacillaene, macrolactin, butirosin, bacilysin, teichuronic acid, bacillibactin, and molybdenum cofactor). In support of this finding, B. velezensis VTX9 exhibited strong antibacterial activity against some Gram-negative pathogens, including Escherichia coli ATCC 11105, S. typhimurium ATCC 14028, and Gram-positive pathogens, including S. epidermidis ATCC 12228, M. luteus ATCC 9341, S. aureus ATCC 6538 (Fig. 1d).

\section{Production of EPS}

EPS is one important factor contributing to the adhesive ability of probiotic bacteria to the intestinal mucosa through biofilm formation (Caggianiello et al. 2016, Wu et al. 2020). Genome analysis revealed the complete EPS biosynthetic gene clusters containing 15 eps genes (epsO, epsN, epsM, epsL, epsK, epsJ, epsI, epH, epsG, epsF, epsE, eps $D, e p s C, e p s B, e p s A$ ) and one transcriptional factor slrR (Fig. 5a). All eps genes are located in the same orientation. This cluster is conserved across B. velezensis strains and contains four types of functional proteins including regulation, biosynthesis of repeating units, polymerization and chain-length determination, and export (Wu et al. 2020). The presence of transcriptional

Table 2 Secondary metabolite biosynthetic gene clusters determined in B. velezensis VTX9

\begin{tabular}{llll}
\hline Metabolites & Synthetase & MIBiG BGC (similarity) & Bioactive spectrum \\
\hline Difficidin & TransATPKS & BGC0000176 (100\%) & Bacteria \\
Fengycin & TransATP KS- NRPS & BGC0001095 (100\%) & Fungi \\
Bacillaene & TransATP KS-NRPS & BGC0001089 (100\%) & Bacteria \\
Macrolactin & TransATPKS & BGC0000181 (100\%) & Bacteria \\
Butirosin & Other KS & BGC0000693 (7\%) & Bacteria \\
Surfactin & NRPS & BGC0000433 (82\%) & Virus, fungi \\
Bacilysin & NRPS & BGC0001184 (100\%) & Bacteria, yeast \\
Teichuronic acid & Saccharide & BGC0000868 (100\%) & Bacteria \\
Bacillibactin & NRPS & BGC0000309 (100\%) & Microbes \\
Molybdenum cofactor & NRPS & BGC0000916 (17\%) & Bacteria \\
\hline
\end{tabular}




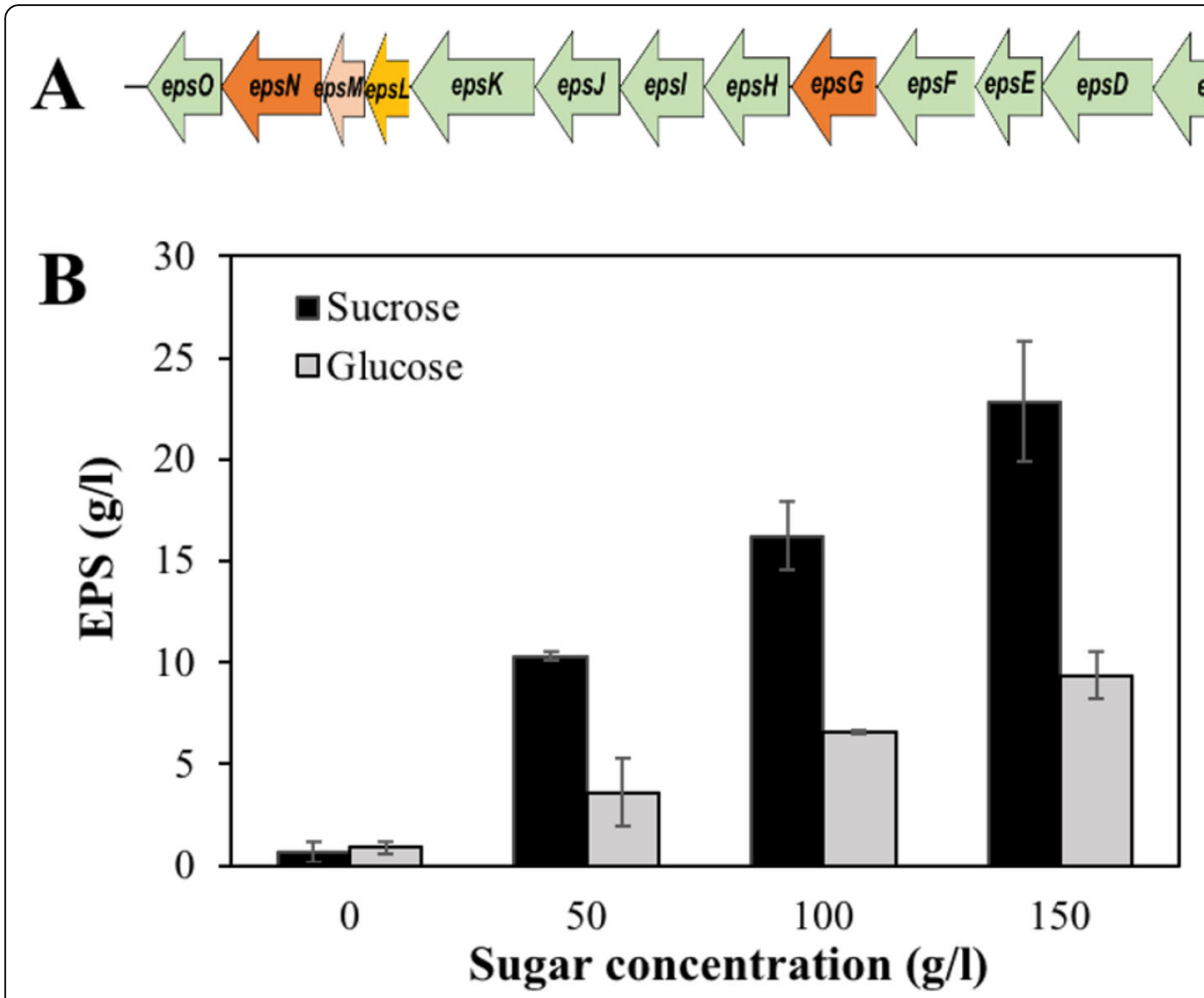

Fig. 5 EPS biosynthesis in B. velezensis VTX9. Genetic organization of EPS synthetic gene cluster (a). The effect of glucose and sucrose to EPS production (b)

factor slrR confirmed that EPS biosynthesis is directly regulated by SlrR. Both epsA and epsB are responsible for the polymerization and chain length determination process. The genes epsF, epsG, epsH, epsI, epsJ, and epsK function in transferring a variety of nucleotide sugars, while epsC, epsI, epsO, eps $M$, and eps $N$ catalyze the modification of polysaccharide repeating units.

Using glucose as a carbon source, strain VTX9 started EPS production at $50 \mathrm{~g} / \mathrm{l}$ glucose, and yielded the highest EPS of $9.4 \pm 1.16 \mu \mathrm{g} / \mathrm{l}$ when supplemented with $150 \mathrm{~g} / \mathrm{l}$ glucose (Fig. 5b). Different from glucose, the use of sucrose is more advantageous for the production of EPS. The biosynthesis of EPS in the strain VTX9 reached 10.3 $\pm 1.16 \mathrm{~g} / \mathrm{l}$ at sucrose concentration of $50 \mathrm{~g} / \mathrm{l}$, which was equal to the highest EPS concentration recorded when using glucose. The greatest EPS yield of $22.8 \pm 2.97 \mathrm{~g} / \mathrm{l}$ was observed in a medium with $150 \mathrm{~g} / \mathrm{l}$ sucrose.

\section{Discussion}

Due to the ban on antibiotics as growth promoters in animal farming, the supplementation of probiotic bacteria as a feed additive has been enticing attention over the past decades. B. velezensis is only known as a biocontrol and plant-growth promoting bacterium. Although $B$. velezensis has been recently applied as a feed additive for improving the growth and health status of livestock, the biosafety and probiotic properties have not been fully reported at the phenotypic and genetic levels. In this study, we, for the first time, shed light on genome determinants involved in probiotic traits of $B$. velezensis VTX9 applicable in swine farming.

Despite various beneficial effects in animal production, biosafety for host and the environment is frequently cited as a concern. According to the latest classification, $B$. amyloliquefaciens subsp. plantarum, $B$. methylotrophicus, and $B$. oryzicola are members of $B$. velezensis. Previously, B. amyloliquefaciens, which was used for food processing industries, was recognized as a GRAS organism approved by FDA (de Boer Sietske and Diderichsen 1991). However, B. velezensis has not yet been considered. To be a safe Bacillus candidate, enterotoxin genes, including four $h b l A, h b l C, h b l D$, three nhe $A$, nheB, nheC, four cesA, cesB, cesC, cesD, and one hlyII, bceT, cytK, should be absent in the genome (Fu et al. 2019), which matched the genomic analysis of B. velezensis VTX9. In support of this result, this strain did not produce $\alpha$ - or $\beta$-hemolytic activity after incubation on blood agar plates for $24 \mathrm{~h}$ (unshown data). Furthermore, the possibility of passing antibiotic resistance genes from probiotic bacteria to commensals and pathogens through 
horizontal gene transfer is a concerning issue (Selvin et al. 2020). In this study, the transferrable antibiotic resistance genes were not found in the chromosome and five plasmids. Additionally, B. velezensis VTX9 is susceptible to 10 antibiotics, including kanamycin, levofloxacin, neomycin, ciprofloxacin, gentamicin, amikacin, nalidixic acid, ceftazidime, tetracycline, and fosfomycin (Table S1). A latest study proved that the supplementation of $B$. velezensis in diets of laying hens significantly enhanced egg production rate, egg quality, and plasma biochemical index (Ye et al. 2020). Thus, B. velezensis could replace flavomycin that is a growth promoter in livestock production (Limede et al. 2021). EFSA also approved the use of Calsporin ${ }^{\circ}$ containing viable spore of $B$. velezensis DSM 15544 as a feed additive for weaned piglets and fattening pigs. These findings further strengthened the biosafety of $B$. velezensis VTX9 in swine farming.

Genomically, B. velezensis VTX9 encodes 43 genes related to resistance to oxidative stress, among which genes involved in the functioning of $\mathrm{BrxABC} / \mathrm{BSH} / \mathrm{YpdA}$ and $\operatorname{Trx} / \operatorname{TrxR}$ systems were fully described for the first time in B. velezensis. trx and trxR exist as one copy in the chromosome of B. subtilis, contributing to high sensitivity to $1 \mathrm{mM} \mathrm{H}_{2} \mathrm{O}_{2}$ (Zheng et al. 2019, Arias Padró et al. 2021). By contrast, B. velezensis VTX9 conferred resistance to $3 \mathrm{mM} \mathrm{H}_{2} \mathrm{O}_{2}$ by harboring 9 genes involved in Trx/TrxR system. ohrB-ohrR-ohrA1 and ohrR-ohrA2 operons responsible for detoxification of organic hydroperoxide and hydrogen peroxide stress were observed in the VTX9 genome, while only one ohrR-ohrA operon was identified in B. subtilis (Chi et al. 2011). Since exposure to bile salts and acidic $\mathrm{pH}$ cause ROS and oxidative DNA damage, leading to cell death (Begley et al. 2005), the distribution of nonenzymatic and enzymatic antioxidants suggested the potential capability of strain VTX9 to survive in harsh conditions encountered in the gastrointestinal tract of pigs.

The commensal colonic bacteria are known to be a significant source of water-soluble vitamins such as riboflavin. Due to the inability to synthesize vitamins, humans and aminals have to absorb riboflavin from exogenous sources such as the diet and gut-associated microorganisms (Rossi et al. 2011). In pig production, deficiency of this vitamin resulted in a reduced feed intake, impaired reproduction, retarded growth, and nervous disorders (Pettigrew et al. 1996, Khan et al. 2020). Feeding diets supplemented with riboflavin led to decreased stress effects, increased growth performance, and improvement of the lean meat percentage of growing-finishing pigs (Shi et al. 2018). In the Bacillus genera encompassing 266 named species, only B. subtilis and $B$. tequilensis are so far reported to produce riboflavin (Averianova et al. 2020). Riboflavin used as a feed additive occupies approximately $70 \%$ on global market, which is mainly yielded by genetically modified microorganisms such as $A$. gossypii, $C$. famata var. flareri, and $B$. subtilis. In this present study, B. velezensis VTX9 harbors 5 genes organized in the rib operon, leading to riboflavin production observed in the supernatant. Interestingly, 3 riboflavin transporters $r i b Z$ are used to transport riboflavin from outside of the cell membrane to the cytoplasm. Under un-optimized conditions, the strain VTX9 produced higher riboflavin levels $(769 \pm 7.5 \mathrm{ng} /$ $\mathrm{ml})$ compared to $L$. plantarum CRL $725(309 \pm 9 \mathrm{ng} /$ $\mathrm{ml})$, Lactococcus lactis subsp. lactis. C173 (223.3 \pm 0.02 $\mathrm{ng} / \mathrm{ml}$ ) (Sabo et al. 2020). However, it was 2.5-fold lower than B. subtilis subsp. subtilis ATCC 6051 (Bacher and Mailänder 1978). This is the first report demonstrating the ability to produce riboflavin of the $B$. velezensis at the genotypic and phenotypic levels. Given that $B$. velezensis VTX9 was isolated from swine feces, this strain could be an alternative means to increase available riboflavin in the digestive tract of pig.

Genome analysis identified the presence of eps operon in B. velezensis VTX9. It is worth noting that this operon is highly conserved $B$. velezensis and $B$. licheniformis strains (Chen et al. 2017, Wu et al. 2020). EPS is one of the important metabolites providing health benefits to the host. A recent study proved that EPS produced by probiotics had strong immunomodulatory, antipathogen, and antioxidant effects in the host's gut (Castro-Bravo et al. 2018, Khalil et al. 2018). Moreover, EPS is required to protect bacterial cells from environmental hazards and improve adhesion and biofilm formation (Khalil et al. 2018). The use of glucose yielded low EPS concentration, while the supplement of sucrose significantly promoted EPS production in strain VTX9. This result suggested that EPS production of B. velezensis VTX9 depends on sugar source supplemented in the liquid medium. The highest EPS production of $22.8 \pm 2.97 \mathrm{~g} / \mathrm{l}$ was recorded after $24 \mathrm{~h}$, which is around 5-fold and 53fold higher than EPS produced by B. licheniformis MS3 and $L$. plantarum WLPL04, respectively (Asgher et al. 2020). Under observation by SEM, the cells were surrounded by sticky material that is supposed to be EPS (Fig. S1). These findings proved that the ability to produce high EPS concentration is one of the outstanding probiotic properties of $B$. velezensis VTX9.

\section{Conclusion}

This study provided valuable insights into essential properties of probiotic B. velezensis VTX9 at the genomic level, which has not been previously reported. The identified genes contributing to desirable probiotic traits such as oxidative stress, acid $\mathrm{pH}$, bile tolerance, and anti-pathogenic activity were revealed through genome analysis. Moreover, this strain possesses the entire metabolic pathways of riboflavin and EPS biosynthesis that 
strengthen its potential application in swine nutrition. These findings presented here provide solid evidence to demonstrate that B. velezensis VTX9 is a suitable probiotic candidate that can be approved by EFSA in the future and could be a new candidate for the industrial application of riboflavin production.

\section{Supplementary Information}

The online version contains supplementary material available at https://doi. org/10.1186/s13213-021-01646-4.

Additional file 1: Table S1. Phenotypic characteristics and antibiotic sensitivity of Bacillus sp. VTX9 and the type strain B. velezensis CR-502 ${ }^{\top}$ Table S2. Genomic features predicted in the chromosome and plasmids of $B$. velezensis VTX9. Fig. S1. Scanning electron microscopic images showing the cell morphology (a) and spore (b) of Bacillus sp. VTX9. Bacillus sp. VTX9 was grown as an overnight culture in the EPS medium at $37^{\circ} \mathrm{C}$. Scale bar is shown in each figure.

\section{Acknowledgements}

The authors would like to thank the support of VAST-Culture Collection of Microorganisms, Institute of Biotechnology, Vietnam Academy of Science and Technology (www.vccm.vast.vn).

\section{Authors' contributions}

NTQ and THNV conceived of this study. NTQ, NAN, THNV, VTN, TLL, and TLB designed and performed the experiments. TTML, HH, CCN, and TNN supervised and implemented the statistical analysis. NTQ, THNV, and QTP wrote the manuscript. HHC, SCK, and QTP improved the writing of the manuscript. The authors read and approved the final manuscript.

\section{Funding}

This study was financially supported by the Vietnam Academy of Science and Technology (VAST) under Grant number: CN40SH.01/18-21.

\section{Availability of data and materials}

Not applicable

\section{Declarations}

Ethics approval and consent to participate

Not applicable

\section{Consent for publication}

The participant has consented to the submission of this article to the journal. We confirm that the manuscript, or part of it, has neither been published nor is currently under consideration for publication. This work and the manuscript were approved by all co-authors.

\section{Competing interests}

The authors declare that they have no competing interests.

\begin{abstract}
Author details
${ }^{1}$ Institute of Biotechnology, Vietnam Academy of Science and Technology, Hanoi 10000, Vietnam. ${ }^{2}$ Graduate University of Science and Technology, Vietnam Academy of Science and Technology, Hanoi 10000, Vietnam. ${ }^{3}$ School of Biotechnology and Food Technology, Hanoi University of Science and Technology, Hanoi 100000, Vietnam. ${ }^{4}$ Vietnam-Russia Tropical Centre, Hanoi 100000, Vietnam.
\end{abstract}

Received: 28 June 2021 Accepted: 14 August 2021

Published online: 07 September 2021

\section{References}

Allen SJ, Martinez EG, Gregorio GV, Dans LF (2010) Probiotics for treating acute infectious diarrhoea. Cochrane Database Syst Rev 2010(11):CD003048CD003048. https://doi.org/10.1002/14651858.CD003048.pub3
Arias Padró MD, Caboni E, Salazar Morin KA, Meraz Mercado MA, Olalde-Portugal $V$ (2021) Effect of Bacillus subtilis on antioxidant enzyme activities in tomato grafting. PeerJ 9:e10984. https://doi.org/10.7717/peerj.10984

Arnér ESJ and Holmgren A (2011) Thioredoxin system. In: M. Schwab Encyclopedia of Cancer. Springer, Berlin

Asgher M, Urooj Y, Qamar SA, Khalid N (2020) Improved exopolysaccharide production from Bacillus licheniformis MS3: Optimization and structural/ functional characterization. Int J Biol Macromol 151:984-992. https://doi.org/1 0.1016/j.jijbiomac.2019.11.094

Averianova LA, Balabanova LA, Son OM, Podvolotskaya AB, Tekutyeva LA (2020) Production of vitamin B2 (Riboflavin) by microorganisms: An overview. Front Bioeng Biotechnol 8:570828. https://doi.org/10.3389/fbioe.2020.570828

Aziz RK, Bartels D, Best AA, DeJongh M, Disz T, Edwards RA, Formsma K, Gerdes S, Glass EM, Kubal M, Meyer F, Olsen GJ, Olson R, Osterman AL, Overbeek RA, McNeil LK, Paarmann D, Paczian T, Parrello B, Pusch GD, Reich C, Stevens R, Vassieva O, Vonstein V, Wilke A, Zagnitko O (2008) The RAST Server: Rapid Annotations using Subsystems Technology. BMC Genomics 9(1):75. https:// doi.org/10.1186/1471-2164-9-75

Bacher A, Mailänder B (1978) Biosynthesis of riboflavin in Bacillus subtilis: function and genetic control of the riboflavin synthase complex. J Bacteriol 134(2): 476-482. https://doi.org/10.1128/jb.134.2.476-482.1978

Balderas-Ruíz KA, Bustos P, Santamaria RI, González V, Cristiano-Fajardo SA, BarreraOrtíz S, Mezo-Villalobos M, Aranda-Ocampo S, Guevara-García ÁA, Galindo E, Serrano-Carreón L (2020) Bacillus velezensis 83 a bacterial strain from mango phyllosphere, useful for biological control and plant growth promotion. AMB Express 10(1):163. https://doi.org/10.1186/s13568-020-01101-8

Begley M, Gahan CG, Hill C (2005) The interaction between bacteria and bile. FEMS Microbiol Rev 29(4):625-651. https://doi.org/10.1016/j.femsre.2004.09. 003

Blin K, Wolf T, Chevrette MG, Lu X, Schwalen CJ, Kautsar SA, Suarez Duran HG, de Los Santos ELC, Kim HU, Nave M, Dickschat JS, Mitchell DA, Shelest E, Breitling R, Takano E, Lee SY, Weber T, Medema MH (2017) antiSMASH 4.0improvements in chemistry prediction and gene cluster boundary identification. Nucleic Acids Res 45(W1):W36-w41. https://doi.org/10.1093/na r/gkx319

de Boer SA, Diderichsen B (1991) On the safety of Bacillus subtilis and B. amyloliquefaciens: a review. Appl Microbiol Biotechnol 36(1):1-4. https://doi. org/10.1007/BF00164689

Bujnakova D, Strakova E, Kmet V (2014) In vitro evaluation of the safety and probiotic properties of Lactobacilli isolated from chicken and calves. Anaerobe 29:118-127. https://doi.org/10.1016/j.anaerobe.2013.10.009

Caggianiello G, Kleerebezem M, Spano G (2016) Exopolysaccharides produced by lactic acid bacteria: from health-promoting benefits to stress tolerance mechanisms. Appl Microbiol Biotechnol 100(9):3877-3886. https://doi.org/1 0.1007/s00253-016-7471-2

Cai XC, Liu CH, Wang BT, Xue YR (2017) Genomic and metabolic traits endow Bacillus velezensis CCO9 with a potential biocontrol agent in control of wheat powdery mildew disease. Microbiol Res 196:89-94. https://doi.org/10.1 016/j.micres.2016.12.007

Castro-Bravo N, Wells JM, Margolles A, Ruas-Madiedo P (2018) Interactions of surface exopolysaccharides from Bifidobacterium and Lactobacillus within the intestinal environment. Front Microbiol 9:2426. https://doi.org/10.3389/ fmicb.2018.02426

Chen Z, Liu P, Li Z, Yu W, Wang Z, Yao H, Wang Y, Li Q, Deng X, He N (2017) Identification of key genes involved in polysaccharide bioflocculant synthesis in Bacillus licheniformis. Biotechnol Bioeng 114(3):645-655. https://doi.org/1 $0.1002 /$ bit.26189

Chen L, Gu W, Xu H-Y, Yang G-L, Shan X-F, Chen G, Wang C-F, Qian A-D (2018) Complete genome sequence of Bacillus velezensis 157 isolated from Eucommia ulmoides with pathogenic bacteria inhibiting and lignocellulolytic enzymes production by SSF. 3. Biotech 8(2):114-114. https://doi.org/10.1007/ s13205-018-1125-2

Chi BK, Gronau K, Mäder U, Hessling B, Becher D, Antelmann H (2011) Sbacillithiolation protects against hypochlorite stress in Bacillus subtilis as revealed by transcriptomics and redox proteomics. Mol Cell Proteomics 10(11):M111.009506. https://doi.org/10.1074/mcp.M111.009506

Couvin D, Bernheim A, Toffano-Nioche C, Touchon M, Michalik J, Néron B, Rocha EPC, Vergnaud G, Gautheret D, Pourcel C (2018) CRISPRCasFinder, an update of CRISRFinder, includes a portable version, enhanced performance and integrates search for Cas proteins. Nucleic Acids Res 46(W1):W246-w251. https://doi.org/10.1093/nar/gky425 
Dunlap CA, Kim SJ, Kwon SW, Rooney AP (2016) Bacillus velezensis is not a later heterotypic synonym of Bacillus amyloliquefaciens; Bacillus methylotrophicus, Bacillus amyloliquefaciens subsp. plantarum and 'Bacillus oryzicola' are later heterotypic synonyms of Bacillus velezensis based on phylogenomics. Int J Syst Evol Microbiol 66(3):1212-1217. https://doi.org/10.1099/ijsem.0.000858

EFSA Panel on Additives and Products or Substances used in Animal Feed (FEEDAP), Bampidis V, Azimonti G, MdL B, Christensen H, Dusemund B, Fašmon Durjava M, Kouba M, López-Alonso M, López Puente S, Marcon F, Mayo B, Pechová A, Petkova M, Ramos F, Sanz Y, Villa RE, Woutersen R, Cocconcelli PS, Glandorf B, Herman L, Maradona MP, Saarela M, Anguita M, Galobart J, Holczknecht O, Manini P, Pizzo F, Tarrés-Call J, Pettenati E (2020) Assessment of the application for renewal of the authorisation of Calsporin ${ }^{\circledast}$ (Bacillus velezensis DSM 15544) as a feed additive for weaned piglets. EFSA J 18(11):e06283. https://doi.org/10.2903/j.efsa.2020.6283

Elshaghabee FMF, Rokana N, Gulhane RD, Sharma C, Panwar H (2017) Bacillus as potential probiotics: Status, concerns, and future perspectives. Front Microbiol 8:1490. https://doi.org/10.3389/fmicb.2017.01490

Fan B, Blom J, Klenk H-P, Borriss R (2017) Bacillus amyloliquefaciens, Bacillus velezensis, and Bacillus siamensis form an "Operational Group B. amyloliquefaciens" within the B. subtilis species complex. Front Microbiol 8: 22-22. https://doi.org/10.3389/fmicb.2017.00022

Fu R, Chen D, Tian G, Zheng P, Mao X, Yu J, He J, Huang Z, Luo Y, Yu B (2019) Effect of dietary supplementation of Bacillus coagulans or yeast hydrolysates on growth performance, antioxidant activity, cytokines and intestinal microflora of growing-finishing pigs. Anim Nutr 5(4):366-372. https://doi. org/10.1016/j.aninu.2019.06.003

Galperin MY, Makarova KS, Wolf Yl, Koonin EV (2015) Expanded microbial genome coverage and improved protein family annotation in the COG database. Nucleic Acids Res 43(Database issue):D261-D269. https://doi.org/1 0.1093/nar/gku1223

Gopalakrishnan S, Pande S, Sharma M, Humayun P, Kiran BK, Sandeep D, Vidya MS, Deepthi K, Rupela O (2011) Evaluation of actinomycete isolates obtained from herbal vermicompost for the biological control of Fusarium wilt of chickpea. Crop Prot 30(8):1070-1078. https://doi.org/10.1016/j.cropro.2011.03.006

Hart T, Moffat J (2016) BAGEL: a computational framework for identifying essential genes from pooled library screens. BMC Bioinformatics 17(1):164. https://doi.org/10.1186/s12859-016-1015-8

Holzapfel WH, Haberer P, Geisen R, Björkroth J, Schillinger U (2001) Taxonomy and important features of probiotic microorganisms in food and nutrition. Am J Clin Nutr 73(2 Suppl):365s-373s. https://doi.org/10.1093/ajen/73.2.365s

Hong HA, Duc le H, Cutting SM (2005) The use of bacterial spore formers as probiotics. FEMS Microbiol Rev 29(4):813-835. https://doi.org/10.1016/j. femsre.2004.12.001

Jia B, Raphenya AR, Alcock B, Waglechner N, Guo P, Tsang KK, Lago BA, Dave BM Pereira S, Sharma AN, Doshi S, Courtot M, Lo R, Williams LE, Frye JG, Elsayegh T, Sardar D, Westman EL, Pawlowski AC, Johnson TA, Brinkman FS, Wright GD, McArthur AG (2017) CARD 2017: expansion and model-centric curation of the comprehensive antibiotic resistance database. Nucleic Acids Res 45(D1):D566-d573. https://doi.org/10.1093/nar/gkw1004

Jones P, Binns D, Chang HY, Fraser M, Li W, McAnulla C, McWilliam H, Maslen J, Mitchell A, Nuka G, Pesseat S, Quinn AF, Sangrador-Vegas A, Scheremetjew M, Yong SY, Lopez R, Hunter S (2014) InterProScan 5: genome-scale protein function classification. Bioinformatics 30(9):1236-1240. https://doi.org/10.1 093/bioinformatics/btu031

Juarez del Valle M, Laiño JE, Savoy de Giori G, LeBlanc JG (2014) Riboflavin producing lactic acid bacteria as a biotechnological strategy to obtain bioenriched soymilk. Food Res Int 62:1015-1019. https://doi.org/10.1016/j. foodres.2014.05.029

Khalil ES, Abd Manap MY, Mustafa S, Alhelli AM, Shokryazdan P (2018) Probiotic properties of exopolysaccharide producing Lactobacillus strains isolated from Tempoyak. Molecules 23(2):398. https://doi.org/10.3390/molecules23020398

Khan MZ, Khan A, Xiao J, Dou J, Liu L, Yu Y (2020) Overview of folic acid supplementation alone or in combination with vitamin B12 in dairy cattle during periparturient period. Metabolites 10(6):263. https://doi.org/10.3390/ metabo10060263

Khatri I, Sharma S, Ramya TNC, Subramanian S (2016) Complete genomes of Bacillus coagulans S-lac and Bacillus subtilis TO-A JPC, two phylogenetically distinct probiotics. PLoS One 11(6):e0156745. https://doi.org/10.1371/journal. pone.0156745

Khatri I, Sharma G, Subramanian S (2019) Composite genome sequence of Bacillus clausii, a probiotic commercially available as Enterogermina ${ }^{\oplus}$, and insights into its probiotic properties. BMC Microbiol 19(1):307. https://doi. org/10.1186/s12866-019-1680-7

Kim SY, Song H, Sang MK, Weon HY, Song J (2017) The complete genome sequence of Bacillus velezensis strain $\mathrm{GH} 1-13$ reveals agriculturally beneficial properties and a unique plasmid. J Biotechnol 259:221-227. https://doi.org/1 0.1016/j.jbiotec.2017.06.1206

La Ragione RM, Woodward MJ (2003) Competitive exclusion by Bacillus subtilis spores of Salmonella enterica serotype Enteritidis and Clostridium perfringens in young chickens. Vet Microbiol 94(3):245-256. https://doi.org/1 0.1016/s0378-1135(03)00077-4

La Ragione RM, Casula G, Cutting SM, Woodward MJ (2001) Bacillus subtilis spores competitively exclude Escherichia coli O78:K80 in poultry. Vet Microbiol 79(2):133-142. https://doi.org/10.1016/s0378-1135(00)00350-3

Lee I, Ouk Kim Y, Park SC, Chun J (2016) OrthoANI: An improved algorithm and software for calculating average nucleotide identity. Int J Syst Evol Microbiol 66(2):1100-1103. https://doi.org/10.1099/ijsem.0.000760

Lee N-K, Kim W-S, Paik H-D (2019) Bacillus strains as human probiotics: characterization, safety, microbiome, and probiotic carrier. Food Sci Biotechnol 28(5):1297-1305. https://doi.org/10.1007/s10068-019-00691-9

Li P, Tian W, Jiang Z, Liang Z, Wu X, Du B (2018) Genomic characterization and probiotic potency of Bacillus sp. DU-106, a highly effective producer of Llactic acid isolated from fermented yogurt. Front Microbiol 9:2216. https:// doi.org/10.3389/fmicb.2018.02216

Limede AC, Marques RS, Polizel DM, Cappellozza BI, Miszura AA, Barroso JPR, Storti Martins A, Sardinha LA, Baggio M, Pires AV (2021) Effects of supplementation with narasin, salinomycin, or flavomycin on performance and ruminal fermentation characteristics of Bos indicus Nellore cattle fed with forage-based diets. Sci J Anim Sci 99(4):skab005. https://doi.org/10.1093/ jas/skab005

Oliveira D, Vidal L, Ares G, Walter EHM, Rosenthal A, Deliza R (2017) Sensory, microbiological and physicochemical screening of probiotic cultures for the development of non-fermented probiotic milk. LWT Food Sci Technol 79: 234-241. https://doi.org/10.1016/j.lwt.2017.01.020

Overbeek R, Olson R, Pusch GD, Olsen GJ, Davis JJ, Disz T, Edwards RA, Gerdes S, Parrello B, Shukla M, Vonstein V, Wattam AR, Xia F, Stevens R (2014) The SEED and the Rapid Annotation of microbial genomes using Subsystems Technology (RAST). Nucleic Acids Res 42(Database issue):D206-D214. https:// doi.org/10.1093/nar/gkt1226

Paracchini V, Petrillo M, Reiting R, Angers-Loustau A, Wahler D, Stolz A, Schönig B, Matthies A, Bendiek J, Meinel DM, Pecoraro S, Busch U, Patak A, Kreysa J, Grohmann L (2017) Molecular characterization of an unauthorized genetically modified Bacillus subtilis production strain identified in a vitamin B(2) feed additive. Food Chem 230:681-689. https://doi.org/10.1016/j.foodchem.2017. 03.042

Pettigrew JE, el Kandelgy SM, Johnston L, Shurson GC (1996) Riboflavin nutrition of sows. J Anim Sci 74(9):2226-2230. https://doi.org/10.2527/1996.7492226x

Popova T (2017) Effect of probiotics in poultry for improving meat quality. Curr Opin Food Sci 14:72-77. https://doi.org/10.1016/j.cofs.2017.01.008

Quach NT, Nguyen QH, Vu THN, Le TTH, Ta TT, Nguyen TD, Van Doan T, Van Nguyen T, Dang TT, Nguyen XC, Chu HH, Phi QT (2021) Plant-derived bioactive compounds produced by Streptomyces variabilis LCP18 associated with Litsea cubeba (Lour.) Pers as potential target to combat human pathogenic bacteria and human cancer cell lines. Braz J Microbiol. 52(3): 1215-1224. https://doi.org/10.1007/s42770-021-00510-6

Rechenchoski DZ, Dambrozio AML, Vivan ACP, Schuroff PA, Burgos TDN, Pelisson M, Perugini MRE, Vespero EC (2017) Antimicrobial activity evaluation and comparison of methods of susceptibility for Klebsiella pneumoniae carbapenemase (KPC)-producing Enterobacter spp. isolates. Braz J Microbiol 48(3):509-514. https://doi.org/10.1016/j.bjm.2017.01.008

Reva ON, Swanevelder DZH, Mwita LA, Mwakilili AD, Muzondiwa D, Joubert M, Chan WY, Lutz S, Ahrens CH, Avdeeva LV, Kharkhota MA, Tibuhwa D, Lyantagaye S, Vater J, Borriss R, Meijer J (2019) Genetic, epigenetic and phenotypic diversity of four Bacillus velezensis strains used for plant protection or as probiotics. Front Microbiol 10:2610. https://doi.org/10.3389/ fmicb.2019.02610

Robles Alonso V, Guarner F (2013) Linking the gut microbiota to human health. Br J Nutr 109(Suppl 2):S21-S26. https://doi.org/10.1017/s0007114512005235

Rossi M, Amaretti A, Raimondi S (2011) Folate production by probiotic bacteria. Nutrients 3(1):118-134. https://doi.org/10.3390/nu3010118

Ruas-Madiedo P, de los Reyes-Gavilán CG (2005) Invited Review: Methods for the screening, isolation, and characterization of exopolysaccharides produced by 
lactic acid bacteria. J Dairy Sci 88(3):843-856. https://doi.org/10.3168/jds. S0022-0302(05)72750-8

Sabo SS, Mendes MA, Araújo ES, LBdA M, Makiyama EN, JG LB, Borelli P, Fock RA, Knöbl T, RPdS O (2020) Bioprospecting of probiotics with antimicrobial activities against Salmonella Heidelberg and that produce B-complex vitamins as potential supplements in poultry nutrition. Sci Rep 10(1):7235. https://doi.org/10.1038/s41598-020-64038-9

Saulnier DM, Spinler JK, Gibson GR, Versalovic J (2009) Mechanisms of probiosis and prebiosis: considerations for enhanced functional foods. Curr Opin Biotechnol 20(2):135-141. https://doi.org/10.1016/j.copbio.2009.01.002

Selvin J, Maity D, Sajayan A, Kiran GS (2020) Revealing antibiotic resistance in therapeutic and dietary probiotic supplements. J Glob Antimicrob Resist 22: 202-205. https://doi.org/10.1016/j.jgar.2020.02.007

Shi H, Kim JK, Serpunja S, Hu J, Kim IH (2018) Effects of the inclusion of vitamin B2 by-product on growth performance, blood profiles and meat quality in growing-finishing pigs. J Anim Sci 96(suppl_2):44-44. https://doi.org/10.1093/ jas/sky073.083

Snyder EE, Kampanya N, Lu J, Nordberg EK, Karur HR, Shukla M, Soneja J, Tian Y, Xue T, Yoo H, Zhang F, Dharmanolla C, Dongre NV, Gillespie JJ, Hamelius J, Hance M, Huntington Kl, Jukneliene D, Koziski J, Mackasmiel L, Mane SP, Nguyen V, Purkayastha A, Shallom J, Yu G, Guo Y, Gabbard J, Hix D, Azad AF, Baker SC, Boyle SM, Khudyakov Y, Meng XJ, Rupprecht C, Vinje J, Crasta OR, Czar MJ, Dickerman A, Eckart JD, Kenyon R, Will R, Setubal JC, Sobral BW (2007) PATRIC: the VBI PathoSystems Resource Integration Center. Nucleic Acids Res 35(Database issue):D401-D406. https://doi.org/10.1093/nar/gkl858

Tatusova T, DiCuccio M, Badretdin A, Chetvernin V, Nawrocki EP, Zaslavsky L, Lomsadze A, Pruitt KD, Borodovsky M, Ostell J (2016) NCBI prokaryotic genome annotation pipeline. Nucleic Acids Res 44(14):6614-6624. https://doi. org/10.1093/nar/gkw569

Vu HT, Nguyen DT, Nguyen HQ, Chu HH, Chu SK, Chau MV, Phi QT (2018) Antimicrobial and cytotoxic properties of bioactive metabolites produced by Streptomyces cavourensis YBQ59 isolated from Cinnamomum cassia Prels in Yen Bai province of Vietnam. Curr Microbiol 75(10):1247-1255. https://doi. org/10.1007/s00284-018-1517-X

Wu Y, Wang B, Xu H, Tang L, Li Y, Gong L, Wang Y, Li W (2019) Probiotic Bacillus attenuates oxidative stress- induced intestinal injury via p38-mediated autophagy. Front Microbiol 10:2185-2185. https://doi.org/10.3389/fmicb.2019. 02185

Wu R, Qin Y, Shen Q, Li P (2020) The complete genome sequence of Bacillus velezensis LPL061, an exopolysaccharide-producing bacterium. 3. Biotech 10(6):243. https://doi.org/10.1007/s13205-020-02228-y

Ye M, Wei C, Khalid A, Hu Q, Yang R, Dai B, Cheng H, Wang Z (2020) Effect of Bacillus velezensis to substitute in-feed antibiotics on the production, blood biochemistry and egg quality indices of laying hens. BMC Vet Res 16(1):400. https://doi.org/10.1186/s12917-020-02570-6

Zheng C, Guo S, Tennant WG, Pradhan PK, Black KA, Dos Santos PC (2019) The thioredoxin system reduces protein persulfide intermediates formed during the synthesis of thio-cofactors in Bacillus subtilis. Biochemistry 58(14):18921904. https://doi.org/10.1021/acs.biochem.9b00045

Zhu Z, Peng Q, Man Y, Li Z, Zhou X, Bai L, Peng D (2020) Analysis of the antifungal properties of Bacillus velezensis B-4 through a bioassay and complete-genome sequencing. Front Genet 11:703-703. https://doi.org/10.33 89/fgene.2020.00703

\section{Publisher's Note}

Springer Nature remains neutral with regard to jurisdictional claims in published maps and institutional affiliations.

Ready to submit your research? Choose BMC and benefit from:
- fast, convenient online submission
- thorough peer review by experienced researchers in your field
- rapid publication on acceptance
- support for research data, including large and complex data types
- gold Open Access which fosters wider collaboration and increased citations
- maximum visibility for your research: over 100M website views per year
At BMC, research is always in progress.
Learn more biomedcentral.com/submissions

